\title{
KAJIAN NARATIF KONSEP MEMINTA TANDA BERDASARKAN HAKIM-HAKIM 6:1-40 DAN IMPLIKASINYA BAGI IMAN ORANG PERCAYA
}

\author{
Hizkia Yonathan Lalu, Peniel C. D. Maiaweng
}

\begin{abstract}
Abstrak
Meminta tanda merupakan hal yang kerap kali dilakukan oleh orang percaya. Biasanya, permintaan tanda dilakukan oleh orang percaya apabila orang percaya tersebut diperhadapkan dengan pilihan-pilihan, maupun di saat imannya terguncang di dalam menghadapi pergumulan dan memerlukan jawaban dari Tuhan. Namun, praktik meminta tanda yang dilakukan oleh orang percaya cenderung tidak memiliki dasar Alkitabiah yang kuat dan bahkan menimbulkan perbedaan pendapat antara golongan-gologan tertentu. Golongan tertentu menganggap meminta tanda boleh dilakukan, sedangkan golongan lain berpendapat sebaliknya, bahkan ada golongan yang sama sekali netral. Kasus meminta tanda terjadi beberapa kali di dalam Alkitab, dan salah satu narasi yang sangat jelas membicarakan tentang meminta tanda adalah narasi tentang Gideon di dalam kitab Hakimhakim 6:1-40. Gideon adalah seorang Israel biasa, yang juga melakukan kesehariannya dengan rasa takut kepada orang Midian, tetapi Malaikat Tuhan menampakkan diri kepadaNya dan menyatakan bahwa Dia akan membebaskan orang Israel melalui Gideon. Gideon akhirnya meminta tanda untuk memastikan panggilan yang telah diterimanya tersebut, bukan satu atau dua kali, tetapi tiga kali. Penulis menggunakan prinsip hermeneutik dan prinsip analisa narasi di dalam meneliti Hakim-hakim 6:1-40, yakni analisa genre, struktur, dan narasi. Penulis mencoba untuk menarik suatu konsep meminta tanda yang implikasinya baik secara teologi maupun praktis sesuai dengan kebenaran Alkitab. Kesimpulan yang ditarik oleh penulis adalah bahwa meminta tanda di dalam konteks Hakim-hakim 6, berlaku untuk orang-orang percaya yang memerlukan peneguhan akan panggilan Tuhan untuk melakukan pekerjaan-Nya.
\end{abstract}

Kata-kata Kunci: Tuhan, Tanda, Gideon, Orang percaya, Panggilan, Membebaskan

\section{Pendahuluan}

\section{Latar Belakang Masalah}

Tanda, mukjizat dan kesembuhan dari Tuhan merupakan hal yang banyak dicari oleh orang percaya. Alhasil, banyak orang percaya yang datang kepada Tuhan meminta di dalam doa dengan mengharapkan tanda, mukjizat dan kesembuhan yang dicarinya terjadi. Bahkan, menurut David J. Smith, 86\% orang Amerika percaya bahwa doa dapat menyembuhkan orang. ${ }^{1}$ Tetapi, apabila hal yang diminta tidak terjadi, kecenderungannya adalah orang tersebut akan kecewa kepada Tuhan.

1 David J. Smith, Bagaimana Aku Dapat Meminta Allah Untuk Kesembuhan Fisik: Panduan Alkitabiah (Makassar: Sekolah Tinggi Theologia Jaffray Makassar, 2013), 9. 
Yancey menyatakan dalam bukunya bahwa ia menemukan jurang antara teori dan praktik doa. "Secara teoritis, doa merupakan sikap dasar manusia, suatu poin tak ternilai mengenai kontak dengan Allah semesta alam. Namun dalam praktiknya, doa seringkali membingungkan dan penuh kekecewaan. Penerbit saya mengadakan jajak pendapat lewat website. Dari 678 responden, hanya 23 orang yang mengaku puas dengan waktu yang mereka habiskan untuk berdoa." ${ }^{2}$ Meminta tanda dilakukan di dalam doa, dan karena pemahaman tentang meminta tanda di dalam Alkitab kurang begitu transparan, terjadilah kesimpangsiuran di dalam praktiknya. Akhirnya kebanyakan pengajaran tentang tanda berpusat kepada pengalaman. Daniel Ronda menganggap bahwa pengajaran berdasarkan pengalaman tidak dapat dipertanggungjawabkan, dan hal seperti ini adalah kecenderungan sekaligus kelemahan dari gereja yang menganut gerakan karismatik di dalam praktik pengajarannya. ${ }^{3}$

Meminta tanda kepada Tuhan biasanya dilakukan oleh orang yang sedang berada di dalam keragu-raguan. Kadang kala, ada lebih dari dua pilihan yang dapat ditempuh dan sangat mirip sehingga sangat sulit untuk mengetahui pilihan mana yang harus diambil. ${ }^{4}$

Keraguan yang hampir serupa juga dialami oleh seorang hakim yang bernama Gideon, yang Tuhan angkat sebagai seorang hakim untuk membebaskan bangsa Israel dari penindasan. Definisi hakim yang ada pada masa Perjanjian Lama sangat berbeda dengan hakim pada masa modern. Blommendaal menyatakan bahwa hakim yang dimaksud di dalam Perjanjian Lama adalah pemimpin satu dua suku Israel yang memimpin peperangan pada masa perang. ${ }^{5}$ Meskipun Tuhan yang secara langsung mengutus dia, ia merasa belum yakin dengan panggilan yang diterimanya. Sebelum Gideon mencapai kemenangan sebagai seorang hakim, ada pengalaman yang harus Gideon lewati terlebih dahulu. Kepahlawanan Gideon bukanlah pembawaannya yang asli, melainkan akibat dari pengalaman rohani, seperti yang dikemukakan oleh Baxter. ${ }^{6}$

Gideon yang meminta tanda dari Tuhan, menjadi percaya bahwa Tuhanlah yang mengutusnya untuk membebaskan bangsa Israel dari tangan orang Midian setelah Tuhan menunjukan tanda (lih. Hak 6:21-24). Menurut Wycliffe, tindakan adikodrati ini diminta Gideon untuk menegaskan bahwa memang benar bahwa pesan ini adalah dari Tuhan. ${ }^{7}$ Setelah percaya, Gideon melakukan apa yang Tuhan firmankan kepadanya.

Selang beberapa waktu kemudian, Gideon kembali meminta tanda kepada Tuhan perihal pengutusan-Nya atas Gideon (lih. Hak 36-37). Segera sesudah Tuhan melakukan tanda yang Gideon minta (lih. Hak 6:38), Gideon lagi-lagi meminta tanda dari Tuhan (lih. Hak 6:39). "Tanda ganda yang tidak dapat diterangkan secara alamiah ini merupakan bukti bagi Gideon bahwa Allah akan memberikan kemenangan kepadanya dan pasukan yang dipimpinnya."

Gideon bukanlah satu-satunya tokoh di dalam Perjanjian Lama yang meminta tanda kepada Tuhan, seperti hamba Abraham yang mencari isteri untuk Ishak (lih. Kej 24:1-67), raja Hizkia yang meminta tanda bahwa ia akan benar-benar disembuhkan (lih. 2 Raj 20:111). Meminta tanda berkali-kali dari Tuhan yang dilakukan oleh Gideon, menunjukan betapa Gideon bingung, ragu dan belum yakin akan apa yang harus ia lakukan, meskipun Allah, yang sudah dengan jelas menyatakan bahwa Dialah yang mengutus Gideon (lih.

\footnotetext{
${ }^{2}$ Philip Yancey, Doa: Bisakah Membuat Perubahan? (Jakarta: BPK Gunung Mulia, 2015), 7.

${ }^{3}$ Daniel Ronda, Sistem Berteologi (Tanggerang: PT. Natana Bina Utama, 2015), 134-135.

${ }^{4}$ Elmer L. Towns, Bagaimana Tuhan Menjawab Doa (Jakarta: Nafiri Gabriel, 2010), 169.

${ }^{5}$ J. Blommendaal, Pengantar Kepada Perjanjian Lama (Jakarta: BPK Gunung Mulia, 2018), 71.

${ }^{6}$ J. Sidlow Baxter, Menggali Isi Alkitab (Jakarta: Yayasan Komunikasi Bina Kasih, 2012), 277

${ }^{7}$ Emma Maspaitella (ed.), Tafsiran Alkitab Wycliffe Volume 1 (Malang: Gandum Mas, 2014), 669.

${ }^{8}$ Emma Maspaitella (ed.), Tafsiran Alkitab Wycliffe Volume 1 (Malang: Gandum Mas, 2014), 670.
} 
Hak 6:14). Bahkan, Gideon adalah satu-satunya tokoh di dalam Alkitab yang meminta tanda sampai tiga kali, dan Tuhan melakukan tanda-tanda tersebut baginya. Terlepas dari segala keraguan Gideon, Schultz mengemukakan bahwa hakim-hakim, termasuk Gideon telah melakukan perbuatan-perbuatan yang besar demi kepentingan bangsa Israel. ${ }^{9}$

Alkitab jelas mengajarkan bahwa orang percaya harus berdoa untuk banyak hal. ${ }^{10}$ Doa yang ada diantaranya, doa mengucap syukur, doa permohonan, meminta ampun, dan lain-lain. ${ }^{11}$ Namun demikian, doa meminta tanda tidak pernah menjadi suatu ajaran di dalam Alkitab, baik Perjanjian Lama, maupun Perjanjian Baru. Meminta tanda dari Tuhan ditunjukan hanya dari beberapa kasus yang ada di dalam Alkitab, dan tidak mendapat begitu banyak penjelasan tentang diperbolehkan atau tidaknya hal tersebut dilakukan di dalam Alkitab.

Perbedaan pengalaman berbagai macam orang yang mengalami tanda dari Tuhan, serta perbedaan pandangan teologis menyebabkan munculnya pandangan bahwa meminta tanda kepada Tuhan adalah hal yang aneh. Wilcock menyatakan bahwa menghadapkan Allah dengan ujian-ujian bukanlah suatu cara yang baik bagi orang percaya untuk mencari bimbingan-Nya. ${ }^{12}$ Kaum modernis, sekalipun seringkali berbeda pandangan, menyetujui bahwa mereka tidak mempercayai penyataan lewat tanda. ${ }^{13}$ Berbeda dengan Dave Ealey yang menyatakan, "Walaupun ada beberapa ahli Alkitab dan pendeta terheran-heran jika ada seseorang meminta tanda kepada Allah, saya kira ada peristiwa-peristiwa langka dan khusus di dalam kehidupan kita di mana meminta tanda memang diperbolehkan." ${ }^{14}$ Daniel Ronda juga berpendapat bahwa tanda dan mukjizat merupakan ciri yang dapat ditemui di dalam Perjanjian Lama dan Perjanjian Baru. ${ }^{15}$ Sedangkan orang-orang yang menganut pandangan postmodern berada di posisi netral dengan berpendapat, segala sesuatu bisa menjadi benar apabila dilihat dari prespektif tertentu. ${ }^{16}$

Berbagai pandangan yang timbul perihal meminta tanda kepada Tuhan, menimbulkan suatu masalah. Masalah yang timbul adalah kesimpangsiuran di dalam pemahaman tentang meminta tanda dan bagaimana pemahaman tersebut memberikan dampak bagi iman orang percaya. Berdasarkan latar belakang masalah ini, penulis tertarik untuk menganalisis teks Hakim-hakim 6:1-40 guna menemukan suatu konsep yang sesuai dengan kebenaran Alkitab tentang meminta tanda dan implikasinya terhadap iman orang percaya, melalui suatu kajian naratif dengan judul: KAJIAN NARATIF KONSEP MEMINTA TANDA BERDASARKAN HAKIM-HAKIM 6:1-40 DAN IMPLIKASINYA BAGI IMAN ORANG PERCAYA.

\section{Pokok Masalah}

Berdasarkan latar belakang masalah, maka pokok masalah dalam penulisan karya ilmiah ini yaitu:

Pertama, apakah makna konsep meminta tanda berdasarkan Hakim-hakim 6:1-40?

\footnotetext{
${ }^{9}$ Samuel J. Schultz, Pengantar Perjanjian Lama (Malang: Gandum Mas, 1983), 51.

${ }^{10}$ Mary T. Sweat, “Why Is Prayer Important?” Journal of Christian Nursing 30, no. 3 (2013): 182, https://doi.org/10.1097/CNJ.0b013e3182964b77.

${ }^{11}$ Handreas Hartono, "Membentuk Karakter Kristen Pada Anak Keluarga Kristen,” Kurios 2, no. 1 (2018), 64.

${ }^{12}$ Michael Wilcock, Hakim-Hakim (Jakarta: Yayasan Komunikasi Bina Kasih, 2005), 123.

${ }^{13}$ H. Henry Meeter, Pandangan-Pandangan Dasar Calvinisme (Surabaya: Momentum, 2014), 23.

${ }^{14}$ Dave Earley, The 21 Most Effective Prayers of The Bible (Yogyakarta: ANDI, 2015), 42.

15 Daniel Ronda, Dasar Teologi Yang Teguh (Makassar: Sekolah Tinggi Theologia Jaffray Makassar, 2013), 65.

${ }^{16}$ I. Putu Ayub Darmawan, "Pendidikan Kristen Di Era Postmodern," Jurnal Simpson: Jurnal Teologi Dan Pendidikan Agama Kristen 1, no. 1 (2016), 39.
} 
Kedua, apakah implikasi praktis dari konsep meminta tanda berdasarkan Hakimhakim 6:1-40 bagi iman orang percaya?

\section{Tujuan Penelitian}

Adapun tujuan penelitian karya ilmiah ini adalah:

Pertama, untuk mengkaji dan menjelaskan konsep meminta tanda berdasarkan Hakim-hakim 6:1-40.

Kedua, untuk menjelaskan implikasi teologis dan implikasi praktis dari konsep meminta tanda berdasarkan Hakim-hakim 6:1-40 bagi iman orang percaya.

\section{Manfaat Penelitian}

Adapun manfaat penelitian karya ilmiah ini adalah:

Pertama, karya ilmiah ini dapat menjadi bahan bacaan yang menambah wawasan baik bagi penulis maupun bagi para pembaca.

Kedua, agar pembaca dapat memahami dan mengerti tentang konsep meminta tanda dan dapat mengimplementasikannya di dalam kehidupan.

Ketiga, memenuhi salah satu syarat akademik dalam menyelesaikan tugas program stratum satu (S1) pada Sekolah Tinggi Filsafat Jaffray Makassar.

\section{Metode Penelitian}

Metode penelitian yang digunakan di dalam karya ilmiah ini menggunakan metode kualitatif ${ }^{17}$ dengan penalaran induktif. Tahapan penelitian yang ada di dalam karya ilmiah ini adalah menganalisa kitab Hakim-hakim pada bab 2 (introduksi) yang mencakup gambaran umum, penulis dan tanggal penulisan, tujuan, keunikan, dan garis besar. Pada bab 3 penulis akan menganalisis kesusastraan, analisis narasi serta analisa makna kata terhadap terhadap teks Hakim-hakim 6:1-40 berdasarkan prinsip-prinsip hermeneutik untuk merumuskan konsep meminta tanda yang ada di dalam Hakim-hakim 6:1-40 dan implikasinya bagi iman orang percaya. Metode yang digunakan adalah metode penafsiran narasi karena sesuai dengan genre dari Hakim-hakim 6:1-40, yang merupakan narasi.

"Penafsiran narasi perjanjian lama adalah penafsiran terhadap kisah-kisah Perjanjian Lama, ${ }^{18}$ yang mengacu kepada analisa terhadap kitab-kitab atau bagian-bagian dari kitab-kitab dalam Perjanjian Lama sebagai sebuah kesusastraan yang utuh dengan memfokuskan perhatian pada narator atau pencerita, plot/alur dan adegan, pengulangan dan kata kunci, tokoh, atmosfir, sudut pandang dan pemilihan materi.",19

\section{Batasan Penelitian}

Mengingat ada beberapa kasus meminta tanda di dalam Alkitab, maka penulisan karya ilmiah ini dibatasi dengan hanya berfokus kepada konsep meminta tanda yang terdapat di dalam Hakim-hakim 6:1-40.

\footnotetext{
${ }^{17}$ Metode penelitian kualitatif adalah prosedur penelitian yang menghasilkan data deskriptif berupa kata-kata tertulis atau lisan dari orang-orang dan perilaku yang dapat diamati; I. Wayan Suwendra, Metodologi Penelitian Kualitatif Dalam Ilmu Sosial, Pendidikan, Kebudayaan Dan Keagamaan (Bali: Nilacakra, 2018), 5; Rajo, 144.

18 Peniel C. D. Maiaweng, Penafsiran Narasi Perjanjian Lama (Makassar: Sekolah Tinggi Theologia Jaffray Makassar, 2015), 1. Maiaweng mengutip Richard L. Pratt Jr., Ia Berikan Kisah-Nya (Surabaya: Momentum 2005), xiii.

19 Peniel C. D. Maiaweng, Penafsiran Narasi Perjanjian Lama (Makassar: Sekolah Tinggi Theologia Jaffray Makassar, 2015), 1. Maiaweng mengutip Janice Capel Anderson and Stephen Moore, Mark \& Method: New Approacher in Biblical Studies (Chattanooga: Precept Ministries, 1992), 65.
} 


\section{Sistematika Penulisan}

Sistematika penulisan karya ilmiah ini adalah sebagai berikut:

Bab I, pendahuluan yang berisikan latar belakang masalah, pokok masalah, tujuan penelitian, manfaat penelitian, metode penelitian, batasan penelitian, dan sistematika penulisan.

Bab II, merupakan latar belakang kitab hakim-hakim yang meliputi: gambaran umum kitab Hakim-hakim, penulis dan tanggal penulisan kitab Hakim-hakim, tujuan kitab Hakim-hakim, keunikan kitab Hakim-hakim, dan garis besar kitab Hakim-hakim.

Bab III, berisikan penafsiran narasi Hakim-hakim 6:1-40, meliputi: genre teks, struktur analisa narasi, dan pemahaman meminta tanda.

Bab IV, berisikan implikasi teologis dan implikasi praktis meminta tanda bagi iman orang percaya

Bab V, berisikan kesimpulan dan saran-saran.

\section{Keismpulan}

Kesimpulan yang dapat diambil dari pembahasan kajian naratif konsep meminta tanda berdasarkan Hakim-hakim 6:1-40 dan implikasinya bagi iman orang percaya adalah sebagai berikut:

Pertama, meminta tanda tidak dapat dijadikan sebagai alat penentu setiap keputusan-keputusan yang ada di dalam kehidupan orang percaya. Meminta tanda dititikberatkan hanya kepada ketika orang percaya meragukan panggilan Tuhan untuk melakukan pekerjaan-Nya. Meminta tanda tidaklah mencobai Tuhan.

Kedua, meminta tanda menunjukkan suatu sikap penerimaan dari orang percaya terhadap kuasa Tuhan untuk melakukan mukjizat. Penerimaan yang dimaksud adalah penerimaan dalam arti kepercayaan bahwa Tuhan tidak terbatas dan sanggup melakukan segala sesuatu. Kuasa Allah tidak dibatasi oleh apapun untuk menjawab permintaan tanda.

Ketiga, meminta tanda berfokus kepada kehendak Tuhan. Kondisi permintaan tanda haruslah sesuai dengan kehendak Tuhan. Tuhan akan menjawab permintaan tanda yang diminta karena keraguan akan panggilan untuk pekerjaan-Nya, selama benar adanya bahwa Tuhanlah yang sungguh memanggil untuk melakukan pekerjaan-Nya.

Keempat, implikasi teologis dari meminta tanda adalah menyatakan permintaan atas kasih karunia Tuhan; dan menyatakan permintaan atas mukjizat Tuhan.

Kelima, implikasi praktis dari meminta tanda adalah meminta tanda meneguhkan iman orang percaya untuk melakukan pekerjaan-Nya.

\section{Saran-saran}

Berdasarkan hasil pengkajian tentang konsep meminta tanda berdasarkan Hakimhakim 6:1-40, penulis mengajukan saran-saran, agar tujuan dari skripsi ini dapat tercapai. Saran-saran tersebut adalah sebagai berikut:

Pertama, mengingat bahwa penulis, sekalipun telah berupaya secara maksimal untuk mendapatkan tulisan yang sesuai dengan standar akademis, adalah manusia yang tidak sempurna, penulis bersedia untuk menerima saran dan masukan guna memperbaiki dan menyempurnakan penulisan skripsi ini.

Kedua, mengigat bahwa konsep meminta tanda yang dibahas oleh penulis hanya berfokus kepada Gideon, sedangkan ada kasus-kasus meminta tanda lainnya seperti hamba dari Abraham (Kejadian 4:1-67) dan Tomas (Yohanes 20:25), penulis berharap bahwa karya tulis tentang meminta tanda dari kasus-kasus lain juga dapat diangkat. 
Ketiga, orang percaya harus dapat memahami dan menerima dengan benar konsep meminta tanda yang sesuai dengan kebenaran Alkitab, sehingga dapat mempraktikkannya secara tepat.

\section{Kepustakaan}

Achenebach, Reinhard. Kamus Ibrani - Indonesia Perjanjian Lama. Jakarta: Yayasan Komunikasi Bina Kasih, 2008.

Auld, A. Graeme. Yosua, Hakim-Hakim, Dan Rut. Jakarta: BPK Gunung Mulia, 2017. Baker, David L. Mari Mengenal Arkeologi Alkitab. Jakarta: BPK Gunung Mulia, 2015.

—. Mari Mengenal Perjanjian Lama. Jakarta: BPK Gunung Mulia, 2014.

—. Satu Alkitab Dua Perjanjian: Suatu Studi Tentang Hubungan Teologis Antara Perjanjian Lama Dan Perjanjian Baru. Jakarta: BPK Gunung Mulia, 2015.

Bakker, F. L. Sejarah Kerajaan Allah 1. Jakarta: BPK Gunung Mulia, 2016.

Baxter, J. Sidlow. Menggali Isi Alkitab: Kejadian - Ester. Jakarta: Yayasan Komunikasi Bina Kasih, 2012.

Blommendaal, J. Pengantar Kepada Perjanjian Lama. Jakarta: BPK Gunung Mulia, 2018. Boersema, Jan A. Berteologi Abad XXI. Surabaya: Literatur Perkantas, 2015.

Boice, James Montgomerry. Dasar-Dasar Iman Kristen. Surabaya: Momentum, 2015.

Brill, J. Wesley. Dasar Yang Teguh. Bandung: Kalam Hidup, 2015.

Browning, W. R. F. Kamus Alkitab. Jakarta: BPK Gunung Mulia, 2016.

- Kamus Alkitab. Jakarta: BPK Gunung Mulia, 2016.

Darmawan, I. Putu Ayub. "Pendidikan Kristen Di Era Postmodern." Jurnal Simpson: Jurnal Teologi Dan Pendidikan Agama Kristen 1, no. 1 (2016). 37-46

Douglas, J. D. (ed.). Ensiklopedia Alkitab Masa Kini Jilid 1. Jakarta: Yayasan Komunikasi Bina Kasih, 2011.

_. Ensiklopedia Alkitab Masa Kini Jilid II. Jakarta: Yayasan Komunikasi Bina Kasih, 2011.

—. Tafsiran Alkitab Masa Kini 1: Kejadian - Ester. Jakarta: Yayasan Komunikasi Bina Kasih, 2012.

Dryness, William. Tema-Tema Dalam Teologi Perjanjian Lama. Malang: Gandum Mas, 2001.

Earley, Dave. The 21 Most Effective Prayers of The Bible. Yogyakarta: ANDI, 2015.

Erickson, Millard J. Teologi Kristen Volume Satu. Malang: Gandum Mas, 2014.

Gertz, Jan Christian, Angelika Berlejung, Konrad Schmid, and Markus Witte. Purwa Pustaka: Eksplarisi Ke Dalam Kitab-Kitab Perjanjian Lama Dan Deuterokanonika. Jakarta: BPK Gunung Mulia, 2017.

Hartono, Handreas. "Membentuk Karakter Kristen Pada Anak Keluarga Kristen." Kurios 2, no. 1 (2018): 62-69.

Hill, Andrew E. and John H. Walton. Survey Perjanjian Lama. Malang: Gandum Mas, 2018.

Howard, David M. Kitab-Kitab Sejarah Dalam Perjanjian Lama. Malang: Gandum Mas, 2013.

Hunter, Charles. Mukjizat-Mukjizat Yang Ajaib. Malang: Gandum Mas, 2011.

Juanda. Iman Yang Berwawasan. Bandung: Kalam Hidup, 2006.

Kaiser Jr., Walter. Berkotbah Dan Mengajar Dari Perjanjian Lama. Bandung: Kalam Hidup, 2009.

Maiaweng, Peniel C. D. Penafsiran Narasi Perjanjian Lama. Makassar: Sekolah Tinggi Theologia Jaffray Makassar, 2015. 
Maspaitella, Emma (ed.). Tafsiran Alkitab Wycliffe Volume 1: Kejadian - Ester. Malang: Gandum Mas, 2014.

McCallum, Dennis. Kekristenan Iman Yang Masuk Akal: Alasan-Alasan Kuat Yang Mendasari Kepercayaan Kepada Kristus. Bandung: Kalam Hidup, 2000.

Meeter, H. Henry. Pandangan-Pandangan Dasar Calvinisme. Surabaya: Momentum, 2014.

Ngebbu, Sostenis. Dari Ur-Kasdim Sampai Ke Babel. Bandung: Kalam Hidup, 2007.

Rajo, Gabriel Yobert. "Dosa Yerusalem dalam Yehezkiel 22:1-31: Kajian Biblika dan Implikasi Praktis." Jurnal Ilmu Teologi dan Pendidikan Agama Kristen 1, no. 2 (Desember 2020): 144-162. https://ojs.sttjaffray.ac.id/jitpk/article/view/518.

Ronda, Daniel. Dasar Teologi Yang Teguh. Makassar: Sekolah Tinggi Theologia Jaffray Makassar, 2013. . Sistem Berteologi. Tangerang: Natana Bina Utama, 2015.

Schultz, Samuel J. Pengantar Perjanjian Lama: Taurat Dan Sejarah. Malang: Gandum Mas, 1983.

Smith, David J. Bagaimana Aku Dapat Meminta Allah Untuk Kesembuhan Fisik?:

Panduan Alkitabiah. Makassar: Sekolah Tinggi Theologia Jaffray Makassar, 2013.

Stuart, Douglas. Eksegese Perjanjian Lama. Malang: Gandum Mas, 2012.

Sutanto, Hasan. Hermeneutik: Prinsip Dan Metode Penafsiran Alkitab. Malang: Literatur SAAT, 2007.

Suwendra, I. Wayan. Metodologi Penelitian Kualitatif Dalam Ilmu Sosial, Pendidikan, Kebudayaan Dan Keagamaan. Nilacakra, 2018.

Sweat, Mary T. "Why Is Prayer Important?" Journal of Christian Nursing 30, no. 3 (2013): 178-186. https://doi.org/10.1097/CNJ.0b013e3182964b77.

Thiessen, Henry C. Teologi Sistematika. Malang: Gandum Mas, 2015.

Towns, Elmer L. Bagaimana Tuhan Menjawab Doa. Jakarta: Nafiri Gabriel, 2010.

Wilcock, Michael. Hakim-Hakim. Jakarta: Yayasan Komunikasi Bina Kasih, 2005.

Yancey, Philip. Doa: Bisakah Membuat Perubahan? Jakarta: BPK Gunung Mulia, 2015.

Zuck, Roy B. Teologi Alkitabiah Perjanjian Lama. Malang: Gandum Mas, 2015. 